\title{
Social Representations and Rural Sociability Among Farmers of a Rural Community
}

\author{
Mariana Bonomo - Universidade Federal do Espirito Santo, Vitória, Brasil \\ Lidio de Souza - Universidade Federal do Espirito Santo, Vitória, Brasil \\ Paola Zanotti Epifanio - Universidade Federal do Espirito Santo, Vitória, Brasil \\ Zeidi Aranjo Trindade - Universidade Federal do Espirito Santo, Vitória, Brasil
}

\begin{abstract}
Guided by the Social Representation Theory, this study aims at investigating rural social representations among farmers in State of Espírito Santo - Brazil by analyzing the semantic field associated to the representational object "rural person"; the organizational principles of individual attitude in face of shared content; and the anchoring processes. Two hundred (200) residents, aged between 7 and 81, belonging to four generations of a rural community participated in individual interviews in this study. The results analyzed using software SPAD-T showed that rural sociability is represented from the positive association to the agricultural and community spheres, as well as from the negative comparison between country and city life, which causes feeling of depreciation and critical evaluation about the poor investments in rural areas. It also identified that personal and community values strengthen the positive image of rural identity, showing strategies to maintain the country way of life among different generations in this community.
\end{abstract}

Keywords: rural identity; social representation; rurality; sociability

\section{Representações Sociais e Sociabilidade Rural entre Camponeses de uma Comunidade Rural}

\begin{abstract}
Resumo
Orientado pela Teoria das Representações Sociais, o estudo teve como objetivo investigar as representações sociais de ruralidade entre camponeses do estado do Espírito Santo, através da análise do campo semântico associado ao objeto representacional "pessoas do meio rural", dos princípios organizadores dos posicionamentos individuais frente ao conteúdo compartilhado e dos processos de ancoragem. Por meio de entrevistas individuais, participaram do estudo 200 moradores de quatro gerações de uma comunidade rural, com idades entre 07 e 81 anos. Os resultados, analisados com auxílio do software SPAD-T, indicaram que a sociabilidade rural é representada a partir da associação positiva às esferas agrícola e comunitária, bem como da comparação negativa entre campo-cidade, esta gerando sentimento de desvalorização e avaliação crítica sobre a falta de investimento na zona rural. Identificou-se ainda que valores pessoais e comunitários atuam reforçando a imagem positiva da identidade rural, evidenciando estratégias de manutenção do modo de vida camponês entre as diferentes gerações da comunidade.

Palavras-chave: identidade rural, representação social, ruralidade, sociabilidade
\end{abstract}

Representaciones Sociales y Sociabilidad Rural entre Campesinos de una Comunidad Rural

\begin{abstract}
Resumen
Orientado por la Teoría de Representaciones Sociales, el estudio tuvo como objetivo investigar las representaciones sociales y rurales entre campesinos del estado de Espírito Santo - Brasil, a través de análisis de campo semántico asociado al objeto representativo 'persona del medio rural'; investigar también los principios organizadores de ubicación individual frente al contenido compartido y de los procesos de anclaje. Se realizaron entrevistas individuales con 200 habitantes de cuatro generaciones de una comunidad rural, con edades entre 7 a 81 años. Los resultados analizados con auxilio del software SPAD-T, indicaron que la sociabilidad rural está representada a partir de la asociación positiva con las esferas agrícolas y comunitarias, y también la comparación negativa entre campo-ciudad, está generando sentimientos de desvalorización y evaluación crítica sobre la falta de inversión en la zona rural. Se identificó además que valores personales y comunitarios refuerzan la imagen positiva de la identidad rural, evidenciando estrategias para mantener el modo de vida campesino entre las diferentes generaciones de la comunidad. Palabras-clave: identidad rural; representación social, rural; sociabilidad
\end{abstract}

\section{Introduction}

The concept of urban sociability currently adopted supports the idea that the rural way of life may disappear, as an inevitable consequence of development and the expansion of cities (Del Priore \& Venâncio, 2006). However, contrary to what rural sociology theorists predicted, rural sociability seems to resist the urbanization process, allowing for the configuration of distinct, properly rural social experiences and identities (Bonomo \& Souza, 2010; Carneiro, 2005; Fialho, 2005; Moreira, 1999), comprising the numerous rural identities that mark the Brazilian rurality.

When analyzing the rural context from the perspective of psychosocial phenomena (Howarth, 2006; Jodelet, 2001), it stands out the complexity of the social imaginary that organizes the rural and urban environments, permanently constructed and reconstructed 
from the relationships between social groups that carry meanings that guide representational and identity processes (Moscovici, 1978; Tajfel, 1982). According to Deschamps and Moliner (2009) and Moreira (2005), the construction of social belongingness is markedly a relational process, in which distinct and oppositional identities act in the social relationship established; that is, "ruralities can only exist and be thought from their relations with something that the culture signifies as non-rural" (Moreira, 2005, p. 19).

Despite the movements of affirmation of the rural way of life, evidence points to the reduction of the number of people in the country, a mobility phenomenon that may reflect the effects of the social identification processes with the reference environments (Breakwell, 2001; Carneiro, 2005; Duveen, 2001). According to data presented by the Brazilian Institute of Geography and Statistics - IBGE (2010), only 15\% of the Brazilian population lives in rural areas, a trend also observed in the state of Espírito Santo, region where the present study was conducted, in which only $16 \%$ of the population currently lives in the rural district.

The increasing pressure from urban hegemony reaffirms the need to investigate how rural peasants which are a social minority in the established relational context - have lived this process, once rural individuals have been historically associated to negative stereotypes, which qualify them, for instance, as ignorant and backward (Bonomo, 2010; Del Priore \& Venâncio, 2006).

Given the presented data, this study aimed to investigate the social representations of rural sociability in a socio-cultural community context, once this social setting favors the analysis of representational and social identification processes (Moscovici, 1978; Tajfel, 1982). It should be noted that the community perspective adopted in this context implies the practice of integrative activities, sense of belonging, and existence of social ties among its members (Bonomo, Souza, Melotti \& Palmonari, 2013).

The Theory of Social Representations proposed by Serge Moscovici in 1961 (Jodelet, 2001) is presented as a heuristic and hermeneutic support, both from the epistemological and the methodological perspectives, to analyze phenomena whose central elements are the associations between cognition and social relations. The way we define reality, name and interpret everything around us, establishes a close relationship with social representations, since they are producers as well as products of the psychosocial universe substrate (Moscovici, 1978). The definition of social representation requires, therefore, a very extensive referential of concepts; however, it is important to clarify that it constitutes a way of knowledge, corresponding to a type of social - and practical - thought, which is related to the understanding of reality (Jodelet, 2001).

The great Moscovician theory originated three main approaches: the cultural approach, from Denise Jodelet; the structural approach, from Jean-Claude Abric; and the societal approach, from Willem Doise, being the latter the line of research by the Geneva School, and the one that is adopted as a theoretical reference in the present study. To Doise (1989), social representations must also be studied from a sociological dimension, integration that resulted in the proposition of the four levels of analysis: 1) intraindividual, 2) interpersonal, 3) intergroup, and 4) societal.

Therefore, the Geneva School aims to emphasize the social integration of individuals as a source of variability of social representations (Doise, 2002). This perspective connects the individual to the collective in order to articulate the individual explanations to the societal ones, clarifying the various forms in which subjects place themselves in operation in society. This social dynamism is structured by interactive and positioning ways, or still, by general values and beliefs (Almeida, 2009).

Attempting to explain this interaction, a group of researchers established a theoretical and methodological approach of social representations, i.e., the three-phase model or the three-dimensional approach (Doise, 2002; Clémence, Doise \& Lorenzi-Cioldi, 1994). This model presupposes a hypothesis for each stage of the analysis (Almeida, 2009): 1) shared beliefs (in this phase occurs the identification of the mutual representational field); 2) differences in positioning regarding a given object (at this stage the task is to identify the organizing principles of individual positioning); and 3) the representations are characterized by positioning anchoring (phase in which psychological, social, and psychosocial anchoring are investigated).

In this perspective, psychological anchoring is the one that presents representations by means of their individual modulations. Social anchoring, in turn, corresponds to the gathering of similar social representations from shared experiences and beliefs; and finally, psychosocial anchoring refers to the symbolic link between the subject and society in its plurality of outlooks and values (Almeida, 2009; Bonomo et al., 2013). The analytical perspective of the non-consensual strand of representations derives precisely from 
these three models of anchoring, assuming the study of the principles that rule individual positioning, as well as the sense of social belonging (Clémence et al., 1994).

As an interface phenomenon with social representations (Breakwell, 2001; Duveen, 2001; Duveen \& Lloyd, 1990; Howarth, 2006), social identity has been studied by means of different strategies and theoretical currents, even in the field of Social Representations. Duveen (2001), aiming to identify how social identities are formed and the role of the social representations in this process, argues that identity is constructed both by internal agents of a particular group and by external dimensions. It is not necessarily related to physical likeness or to identical feelings and ideals, and it also allows, as a relational process, for the formation of different social identities associated to the same individual (Howarth, 2002). To Andersén (2010), "social representations function as building blocks for social identities, which in turn create other social representations" (p. 3).

The understanding of identity dynamics implies the analysis of group relations, assuming that the identity of individuals is built according to the groups to which they belong (Bonomo, 2010; Tajfel, 1982). However, when considering that individuals are inserted in different groups, which embody the diverse social categories that constitute the references of sociability (Deschamps \& Moliner, 2009), the analysis goes beyond the investigation of how a determined group perceives itself, and it is also important to reflect on how this is created through alterity relations.

As a "product of a double process of construction and social exclusion that, inextricably linked, such as the two sides of a single sheet of paper, maintain its unity by means of a system of representations," (Jodelet, 1998, pp. 47-48) according to Deschamps and Moliner (2009) and Souza (2004), the interface identityalterity, acts in order to defend the group of belonging, maintenance of identity boundaries, and formulation of positive self-image of individuals associated to determined social belonging. In the search for the positive status, therefore, the identity function of social representations stands out, protecting the specificity of groups (Abric, 2003; Vala \& Lima, 2002), process in which the proposition of the present study is based.

Considering the arguments outlined above, and guided by the Theory of Social Representations, this study aimed to investigate the social representations of rurality among four generations of peasants in a rural community in the state of Espírito Santo, Brazil. Through this research proposal, we seek to understand and analyze how a social group, historically represented by negatively valued meanings and widely propagated in the hegemonic social thought (Del Priore \& Venâncio, 2006; Stropasolas, 2006), elaborates the social representations of their own sociability, i.e., being a rural person.

Given the presented objective and the hypotheses underlying the study of social representations from the theoretical and methodological three-phase model (Berti, Pivetti \& Melotti, 2008; Doise, Clémence \& Lorenzi-Cioldi, 1995), it is likely that the results of this investigation reveal: (a) a shared representational field including both elements present in the hegemonic social representations of rurality and meanings supporting the rural identity to guide the identification process in the different generations of the community; (b) organizing principles based on the thematic universe of rural sociability guided by the relation with nature, way of agricultural production, community values, and elements of comparison countryside-city; (c) anchoring processes from gender and generation belongings influencing the modulation of different representations.

Considering the lack of scientific research on the rural population in the field of Psychology and given the intensification of the rural-urban mobility phenomenon, especially among the rural youth segment, responsible for the reproduction of the local social fabric (Froehlich, Rauber, Carpes \& Toebe, 2011), the study of the identity and representational processes that are configured on the interface between realities and the urbanity-rurality dialogic social categories can contribute to the contextualization of the social reality of rural groups, access to the imaginary of its members on different social objects significant to positioning in their particular context, and in the analysis of the psychosocial processes that contribute to the construction of their social identity.

\section{Method}

\section{Community context}

The research was conducted in a rural community in the state of Espírito Santo including 167 families, with family-based agriculture production (Fialho, 2005; Moreira, 1999), socio-religious model according to the Basic Ecclesial Communities - CEBs (Baltazar, 2004; Mainwaring, 2004), as well as interaction between households and development of community activities, a sociability that also reflects in the educational model present in this context. The school system is based on the pedagogy of alternation (Nosella, 2007), a strategy in 
which the student remains one week studying at school and the other with the family, working on family agriculture and developing school-family-community integrated activities.

The rural context in question can be characterized, therefore, by the sense of belonging to the collective, the existence of beliefs and values, and by the interaction within the families, comprising a field of study favorable to the analysis of social representations (Bonomo \& Souza, 2010; Jodelet, 2001), in which the subject of the representation combines the condition of group belonging and shares meanings about the main social objects in their way of life and social relations.

\section{Participants}

The study was conducted with 200 inhabitants of a rural community in the state of Espírito Santo, aged between 07 and 81 years, representing $34.84 \%$ of the total population in the community where the research was conducted.

The sample is equally distributed regarding the variable gender and the four generational groups in the community, i.e., each group consists of 50 subjects, and 25 females and 25 males from each generation were interviewed.

Next, we present the characterization of participants according to the age groups: (a) the fourth generation ( $n=50)$, composed by the children, with ages ranging between 7 and 12 years, and mean age of 9.88 years $(S D=1.62)$, with all participants regularly attending the local school system; (b) the third generation, comprised by the youth segment of the community $(\mathrm{n}=50)$, including singles with age range from 15 to 25 years $(M=17.72 ; S D=2.54)$. Like the fourth generation, all members of the third generation group were born in this community. Regarding school attendance, in this group, $34 \%$ quit studying (24\% completed high school and 10\% elementary school), $60 \%$ are attending high school (most of them are attending the School of Rural Pedagogy) and 6\% are in higher education; (c) the second generation $(n=50)$, in turn, represents the adult portion of the community or the family heads, in which all members are married and work as rural workers. With $68 \%$ of subjects born in the community, most of them has only primary (52\%) or fundamental $(26 \%)$ education and ages ranging between 35 and 45 years $(M=39.06$; $S D=2.73)$; (d) fourth generation, responsible for the construction of the community, with 60 years or more $(M=67.56 ; S D=5.63)$. In this age group, $18 \%$ are widowers, and it includes people that migrated from other rural areas in the state of Espírito Santo, presenting a mean of 3 years of education. In line with the family agriculture production model, which provides the community's survival, all participants from the first generation are retired as small farmers.

Among the sample characteristics assumed as complementary variables for the analysis of the social anchoring process before the representational field of 'people from the rural environment', the variables gender and generational group were used. These variables were chosen due to the possibility of investigating whether gender and generation belonging contributed to the variability of the representational field and to specific positioning, according to methodological guidance of the three-phase model (Doise, 2002).

\section{Instrument and data collection procedure}

Data collection was carried out in the rural community through individual interviews, at locations indicated by the participants themselves, and according to their availability, respecting the ethical aspects. Following the guidelines of Resolution 466/2012 of the National Health Council, all participants were informed about the study objectives, registering their consent by signing the Informed Consent Form for participation in research projects (for participants under the age of 18, parents/guardians signed the agreement term).

With a standard procedure of data collection and after 12 months of fieldwork by the responsible researcher, all interviews were led exclusively by the main author of this study, and conducted at the homes of participants, at the coffee and pepper plantations, and in the facilities of rural schools (third and fourth generations).

The instrument for data collection was composed by the following sections: (a) identification of social values in the rural environment ("Which values present in the rural environment do you consider the most important for your life"); (b) questions to characterize the sample, such as age, gender, marital status, education, place of birth and profession; as well as (c) free evocations (De Rosa, 2003; Doise et al., 1995) for the inductor terms 'rural' and 'people from the rural environment (or rural people)' ('What do you think, feel, imagine when I say...?'), strategy that enabled us to identify the semantic field associated with these objects.

Concerning the evocation technique or free association technique (Abric, 2003), widely used in studies on social representations, it consists on suggesting a word or inducing expression to the participants, and, 
from this term, they are asked to answer "what do think, feel or imagine," as freely as possible, in relation to the presented object. The goal is to get words or phrases (three to five elements) that will compose the corpus of data on the object of representation, revealing its content more directly.

\section{Data processing}

From the nature of the information collected, we proceeded to cleaning the elements from databases related to the values associated with rurality and to the free evocations of the terms 'rural' and 'rural people'. This process was conducted through Content Analysis (Bardin, 2002, 2003), using the grouping/distinction semantic criterion. Then, the analyzed elements were subjected to the procedures of the SPAD-T program (Lebart, Morineau, BECUE \& Haeusler, 1994). The repetition of the same term among the evocations of the same participant led to the selection of the term in the first position and its suppression in the subsequent positions (Deschamps, 2003).

Through factor correspondence analysis and cluster formation, performed by the SPAD-T software (Villano, Bastianoni \& Melotti, 2001), it was possible to identify the clusters related to the values associated with rural and to the representations relating to the terms 'rural' and 'people from the rural environment/rural people'. The provision of this data set enabled the definition of variables to analyze the anchoring of representations related to the objects in question. The description and analysis of the results refer to the positioning of subjects in the representational field from their sense of belonging in different groups (Doise et al., 1995).

\section{Results}

The presentation of results is organized from three main sections: (1) characterization of the shared representational field for the object 'rural people'; (2) analysis of the organizing principles of social representations of 'rural people'; and (3) analysis of the psychological, social, and psychosocial anchoring processes. This last section is divided into three sets of results, such as: demarcation of the variables that guided the analysis of each anchoring, social representations of 'rural' and social values associated with rural.

\section{Characterization of the shared representational field of 'rural people'}

The corpus of data related to the object of representation 'rural people' was composed of 932 words, considered by the SPAD-T software $86.5 \%$ of the total (806 terms), and a mean of evocation of 4.6 words per respondent. As shown in Table 1, the total of elements related to the object in question had a cut referenced by frequency greater than or equal to $6(f \geq 6)$ and was composed by 38 different components.

The elements that were part of the representational field linked to the object in analysis were gathered in six categories. The developed categories seek to provide an overview of the components of the shared content for 'rural people', enabling a better understanding of identified meanings.

Next, we present the identified categories (Bardin, 2002, 2003): 1) Social interaction: it presents elements linked to how subjects relate to peers and to the groups to which they belong; 2) Social values: it refers to the way subjects value things, according to the assessment of what they consider important in rural sociability; 3) Disadvantages: it includes the critical points and the difficulties faced in the rural context; 4) Rural way: gathers elements that are recurrently assigned to rurality, characterizing the rural way, besides the term nice, which contributes to reinforcing the positive aspects of rural identity; 5) Nature: it integrates meanings related to the way people interact with the environment; 6) Work: it refers to elements that are linked to aspects of labor and the agricultural way of production. The element 'study' was not associated with the created categories, despite being present in evocations.

\section{Analysis of the organizing principles of social representations of 'rural people'}

In the identification of the most significant elements for the constitution of the factors, we assumed an a.c. (absolute contribution) $\geq 100 /$ total number of elements. Considering that the semantic field of the representation object consisted of 38 different terms, there are significant values above 2.63. Table 2 shows the resulting factor plan of the crossing between Factors 1 and 2, related to the representational field of 'rural people'.

Factor 1, resource assessment vs. rural way of life, presents the most significant terms on the left pole (resource assessment): ecological (a.c. =12.2), agriculturalists (a.c. $=10.8$ ), bealthy (a.c.=9.2), poor (a.c.=9.1), sustainable (a.c.=7.3), study (a.c.=5.2) and hardworking (a.c.=3.4), showing aspects related to rural self-sustainability and agricultural work. Opposed to the left pole, the following elements are positioned in the rural way of life pole: 
religious (a.c.=5.3), communicative (a.c.=4.9), interaction (a.c.=4.9), united (a.c.=3.4) and friends (a.c.=3.2), which refer to the relations experienced at the community's interaction context.

While the first factor focuses on the positive aspects of rural life, the second factor presents an assessment of being rural that reflects on the identified polarity (positive and negative images of rural sociability). In the pole positive image of being rural, stands out terms such as bealthy (a.c.=5,3), nice (a.c.=4.8), good (a.c.=4.3), sustainable (a.c.=3.8), ecological (a.c.=3.4) and educated (a.c.=3.1), and in the pole negative image of being rural, in turn, the most significant terms are poor (a.c.=44.0), depreciated (a.c.=9.1) and less study (a.c.=7.3).

\section{Analysis of the anchoring processes}

For the analysis of each type of anchoring (Doise et al., 1995), we chose the following variables, according to each modality of this process: (i) psychological anchoring, evidenced by the formation of clusters, composed by subjects grouped according to the most typical elements of the representations of 'rural people'; (ii) social anchoring, investigated through the projection, in the factorial plan, of the additional variables gender and generation; and finally, (iii) psychosocial anchoring was analyzed through the social representations linked to 'rural and the values associated to rurality, from the projection of the clusters related to these dimensions on the factorial plan of the social representations of 'rural people'.

\section{Psychological Anchoring}

There were three clusters associated to the social representations of 'rural people', named agriculturalists, depreciated and communal, according to their more characteristic content, as shown in Table 3. Such sets of meanings expressed by clusters can be considered social representations specific of the object, according to each grouping of the subjects of the representation (Berti et al., 2008).

With regard to Cluster 1 , consisting of 44 participants, 28 distinct words were evoked 206 times, with a mean of evocation of 4.7 per participant. This group gathers, mostly, meanings related to agriculture, so it was named agriculturalists (Factor 1: Test-V $=-18.4$;

Table 1

Characteristic elements of representations of rural people

\begin{tabular}{|c|c|c|c|c|c|c|c|c|}
\hline cat. 1 & evoked terms & freq. & cat. 2 & evoked terms & freq. & cat.3 & evoked terms & freq. \\
\hline \multirow{12}{*}{ 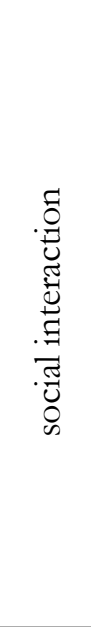 } & friends & 58 & \multirow{12}{*}{ 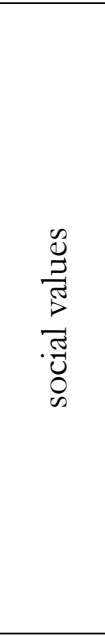 } & supportive & 62 & \multirow{12}{*}{ 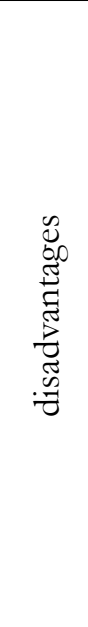 } & poor & 14 \\
\hline & interaction & 38 & & good & 37 & & less study & 13 \\
\hline & communal & 26 & & cheerful & 26 & & depreciated & 10 \\
\hline & united & 23 & & honest & 18 & & old clothes & 07 \\
\hline & communicative & 21 & & equalitarian & 17 & & & \\
\hline & educated & 20 & & religious & 14 & & & \\
\hline & known & 13 & & fighters & 13 & & & \\
\hline & leisure & 11 & & careful & 09 & & & \\
\hline & family & 11 & & responsibility & 08 & & & \\
\hline & playful & 11 & & respectful & 08 & & & \\
\hline & affectionate & 07 & & & & & & \\
\hline & welcoming & 06 & & & & & & \\
\hline cat. 4 & evoked terms & freq. & cat. 5 & evoked terms & freq. & cat.6 & evoked terms & freq. \\
\hline \multirow{6}{*}{ 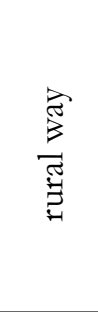 } & simple & 47 & \multirow{6}{*}{ 莺 } & sustainable & 24 & \multirow{6}{*}{$\begin{array}{l}\frac{M}{\overrightarrow{0}} \\
\vec{B}\end{array}$} & hardworking & \\
\hline & our way & 30 & & ecological & 12 & & agriculturalists & \\
\hline & calm & 25 & & healthy & 09 & & & \\
\hline & free & 17 & & & & & & \\
\hline & humble & 16 & & & & & & \\
\hline & nice & 15 & & & & & & \\
\hline
\end{tabular}


Factor 2: Test-V = - 4.4). Cluster 2 groups 14 subjects, with 18 distinct words evoked 63 times, and mean of evocation of 4.5. This group highlights the difficulties associated with the rural context, highlighting meanings that depict the negative dimension of the rural way of life, and for this reason, it was called depreciated (Factor 1: Test- $\mathrm{V}=-8.9$; Factor 2: Test- $\mathrm{V}=19.5)$. Cluster 3 , in turn, assembles the majority of participants, 142 subjects, with evocation mean of 4.7 , and 37 distinct terms mentioned 663 times. In this group the meanings are linked to the sociability of being rural, and on that basis they were named communal (Factor 1: Test-V $=21.7$; Factor 2 : Test $-\mathrm{V}=-6.3)$. Table 2 shows the projection of social representations of 'rural people' in the factorial plan.

\section{Social anchoring}

Among the variables selected for the investigation on social anchoring, we observed the influence of the generation variable while developing the 'rural people' representational field. Together, the meanings that make up the shared field rural people reflect polarities that possibly relate to the groups each individual belongs to (Doise, 2002). That is, belonging to a particular age group makes certain objectives priorities for the group and determines adherence to new practices, which, in turn, influence the social representations of that group (Deschamps \& Moliner, 2009).

Considering Factor 1, which combines components related to the resources assessment (left pole) and to the rural way of life (right pole) we can observe that the individuals of the fourth generation (Factor 1: Test$\mathrm{V}=-6.1)$ corroborate for the resources assessment, while the second generation (Factor 1: Test- $\mathrm{V}=6.3$ ) is related to the assessment of the way of life.

Factor 2, associated to the positive image of the rural person (lower pole), includes members of the fourth generation (Factor 2: Test- $\mathrm{V}=-7.7$ ), which comprise elements with the purpose of favoring the image of the group itself. On the other hand, the negative image of the rural person (upper pole) is linked to individuals of the first (Factor 2: Test-V = 2.4) and third generations (Factor 2: Test-V $=3.7$ ), which may represent the recognition of a negative social status, which is reflected

Table 2

Factorial plan related to the rural people representational field

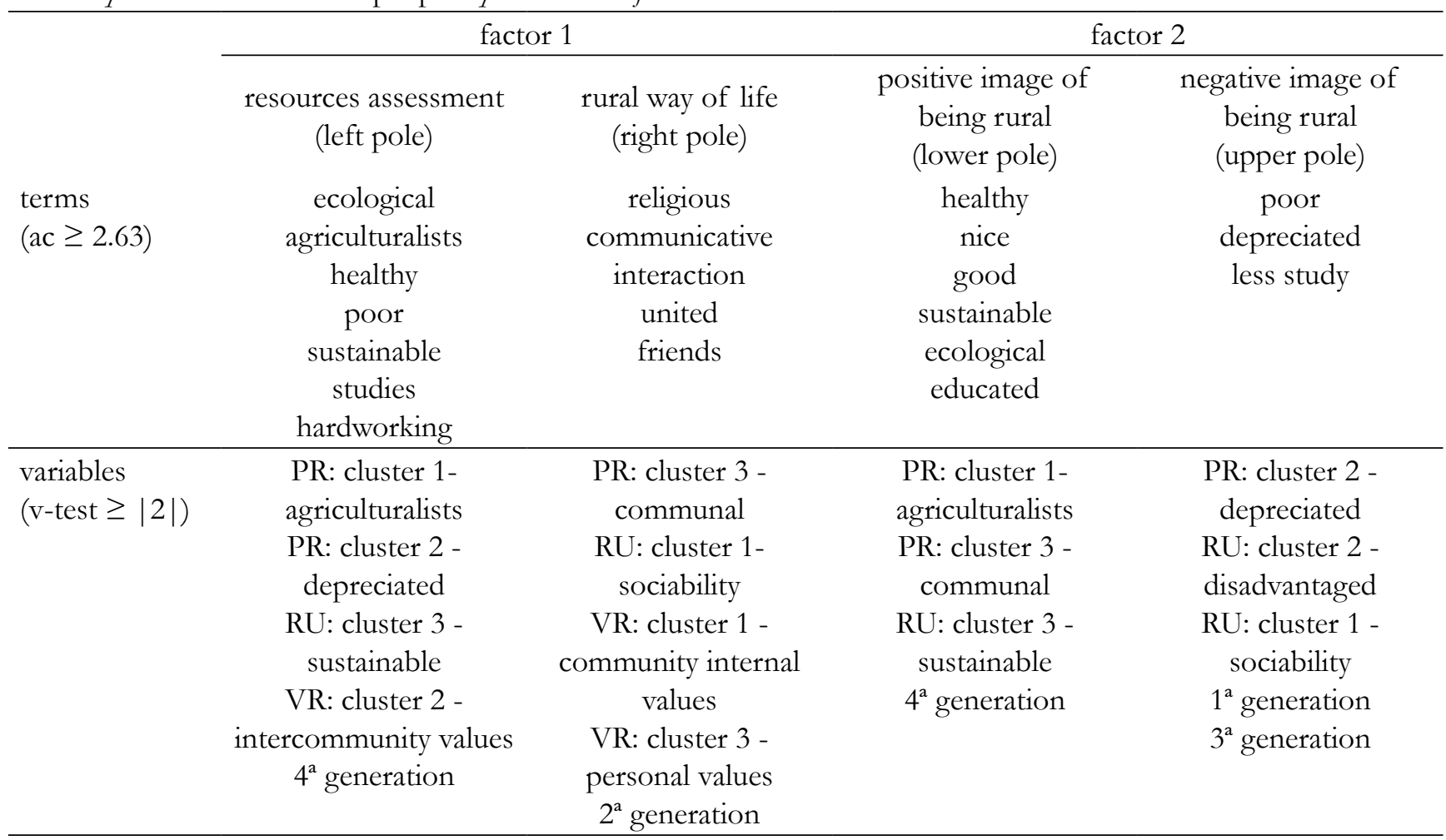

Note. RU = Representation of rural; PR = Representation of rural people; VR = Social values associated to rural. 
in the rural exodus practiced by the third generation. From Table 2, it is possible to observe the projection of the generation variable in the factorial plan.

The variable gender has not proved to be relevant in the positioning of participants before the object in question, since it was not significantly projected in any of the analyzed factors. This finding may be a result of the homogenization of the rural group, which uses such strategy to differentiate from the city group (Vala \& Lima, 2002).

\section{Psychosocial anchoring}

Psychosocial anchoring was investigated by the social representations linked to 'rural' and values associated to rural, through the projection of the clusters related to these dimensions in the factorial plan of the social representations of 'rural people', main object of this research.

Social representations of 'rural'

Regarding the formation of clusters related to the social representations of 'rural', 984 terms and 105 different categories were produced. The cut-off limit adopted for the reduction of the database was a frequency greater than or equal to 6 ( $f \geq 6$ ). Of the 47 elements that were part of the corpus of data relating to 'rural', 34 were recovered by cluster analysis. Aiming to know the positions connected to the 'rural' object, we sought to identify the formation of clusters, as shown in Table 4.
From the projection of the social representations of 'rural' in the factorial plan (see Table 2), it was possible to verify the influence of each cluster in the development of the representational field of 'rural people'. In Factor 1 (resource assessment vs. way of life), we observed that the sociability cluster (Factor 1: Test-V = 6.6) contributes for the assessment of the way of life (right pole) and the sustainable cluster (Factor 1: Test- $\mathrm{V}=-7.6)$ corroborates for the resources assessment (left pole).

With respect to Factor 2 (positive image of being rural vs. negative image of being rural), we verified that both the sociability cluster (Factor 2: Test- $\mathrm{V}=2.7$ ) and the disadvantaged (Factor 2: Test- $\mathrm{V}=4.4$ ) reinforce the negative image of being rural (upper pole), while the sustainable cluster (Factor 2: Test-V = -5.9) contributes to building a positive image of rurality (lower pole).

The development of the 'rural' representational field from the set of identified meanings indicates polarization of the meanings attributed to the object of representation, a fact that was also evident in the analysis of social values concerning rural sociability.

Social values associated to rural

As for the composition of clusters related to the social values associated with rural, a total of 768 terms were produced, and a cutoff limit for the reduction of the frequency database greater than or equal to 6 ( $f \geq 6$ ) was adopted. Therefore, 33 elements were part of the corpus of data related to social values associated with rural.

Table 3

Composition of clusters: social representation of rural people $(V$-test $\geq|2|)$

\begin{tabular}{|c|c|c|c|c|c|}
\hline $\begin{array}{l}\text { cluster } 1 \\
\text { agriculturalists }\end{array}$ & & $\begin{array}{l}\text { cluster } 2 \\
\text { depreciated }\end{array}$ & & $\begin{array}{l}\text { cluster } 3 \\
\text { communal }\end{array}$ & \\
\hline $\begin{array}{l}\text { more frequent } \\
\text { categories }\end{array}$ & $\begin{array}{l}\text { less frequent } \\
\text { categories }\end{array}$ & $\begin{array}{l}\text { more frequent } \\
\text { categories }\end{array}$ & $\begin{array}{l}\text { less frequent } \\
\text { categories }\end{array}$ & $\begin{array}{l}\text { more frequent } \\
\text { categories }\end{array}$ & $\begin{array}{l}\text { less frequent } \\
\text { categories }\end{array}$ \\
\hline agriculturalists & humble & poor & & interaction & hardworking \\
\hline ecological & honest & depreciated & & solidary & depreciated \\
\hline our way & good & less study & & communicative & sustainable \\
\hline free & friends & & & friends & healthy \\
\hline healthy & communicative & & & humble & free \\
\hline sustainable & interaction & & & nice & our way \\
\hline \multirow[t]{4}{*}{ hardworking } & solidary & & & good & ecological \\
\hline & & & & cheerful & poor \\
\hline & & & & educated & agriculturalists \\
\hline & & & & known & \\
\hline
\end{tabular}


Table 4

Cluster composition (categories associated with rural - criterion $V$-test $\geq|2|$ )

\begin{tabular}{|c|c|c|c|c|c|}
\hline \multicolumn{2}{|l|}{$\begin{array}{l}\text { cluster } 1 \\
\text { sociability }\end{array}$} & \multicolumn{2}{|l|}{$\begin{array}{l}\text { cluster } 2 \\
\text { disadvantaged }\end{array}$} & \multicolumn{2}{|l|}{$\begin{array}{l}\text { cluster } 3 \\
\text { sustainable }\end{array}$} \\
\hline $\begin{array}{l}\text { categories of } \\
\text { more frequent } \\
\text { elements }\end{array}$ & $\begin{array}{l}\text { categories of } \\
\text { less frequent } \\
\text { elements }\end{array}$ & $\begin{array}{l}\text { categories of more } \\
\text { frequent elements }\end{array}$ & $\begin{array}{l}\text { categories of } \\
\text { less frequent } \\
\text { elements }\end{array}$ & $\begin{array}{l}\text { categories of } \\
\text { more frequent } \\
\text { elements }\end{array}$ & $\begin{array}{l}\text { categories of } \\
\text { less frequent } \\
\text { elements }\end{array}$ \\
\hline interaction & play & no rural policies & & fruits & freedom \\
\hline way of life & less cars & no money & & animals & calm life \\
\hline amigos & no money & & & houses & work \\
\hline sustainability & school & & & rivers & way of life \\
\hline calm life & woods & & & woods & friends \\
\hline freedom & rivers & & & play & interaction \\
\hline collective & animals & & & school & \\
\hline participation & houses & & & less cars & \\
\hline & no rural & & & plantation & \\
\hline & policies & & & & \\
\hline & fruits & & & & \\
\hline
\end{tabular}

Table 5

Cluster Composition - values associated to rural (more and less frequent- $V$-test $\geq|2|$ )

\begin{tabular}{|c|c|c|c|c|c|}
\hline \multicolumn{2}{|c|}{$\begin{array}{l}\text { cluster } 1 \\
\text { community internal values }\end{array}$} & \multicolumn{2}{|c|}{$\begin{array}{l}\text { cluster } 2 \\
\text { inter-community values }\end{array}$} & \multicolumn{2}{|l|}{$\begin{array}{l}\text { cluster } 3 \\
\text { personal values }\end{array}$} \\
\hline $\begin{array}{l}\text { more frequent } \\
\text { categories }\end{array}$ & $\begin{array}{l}\text { less frequent } \\
\text { categories }\end{array}$ & $\begin{array}{l}\text { more frequent } \\
\text { categories }\end{array}$ & $\begin{array}{l}\text { less frequent } \\
\text { categories }\end{array}$ & $\begin{array}{l}\text { more frequent } \\
\text { categories }\end{array}$ & $\begin{array}{l}\text { less frequent } \\
\text { categories }\end{array}$ \\
\hline $\begin{array}{l}\text { common life } \\
\text { interaction } \\
\text { friendship } \\
\text { family } \\
\text { responsibility } \\
\text { land } \\
\text { religion } \\
\text { will to progress } \\
\text { work } \\
\text { plantation } \\
\text { tradition }\end{array}$ & $\begin{array}{l}\text { alterity } \\
\text { behaves well } \\
\text { sincerity } \\
\text { honors name/ } \\
\text { word } \\
\text { humbleness } \\
\text { dignity } \\
\text { no } \\
\text { discrimination } \\
\text { simplicity } \\
\text { honesty } \\
\text { kindness }\end{array}$ & $\begin{array}{l}\text { kindness } \\
\text { no } \\
\text { discrimination } \\
\text { alterity } \\
\text { peace } \\
\text { behaves well } \\
\text { study } \\
\text { affection with } \\
\text { others } \\
\text { correct person } \\
\text { education } \\
\text { solidarity }\end{array}$ & $\begin{array}{l}\text { oneself } \\
\text { land } \\
\text { responsibility } \\
\text { religion } \\
\text { interaction } \\
\text { work } \\
\text { family } \\
\text { friendship } \\
\text { life in common } \\
\text { honesty }\end{array}$ & $\begin{array}{l}\text { honesty } \\
\text { simplicity } \\
\text { dignity } \\
\text { honors name/ } \\
\text { word } \\
\text { sincerity } \\
\text { humility } \\
\text { be true } \\
\text { share } \\
\text { affection with } \\
\text { others } \\
\text { companionship }\end{array}$ & $\begin{array}{l}\text { land } \\
\text { responsibility } \\
\text { friendship } \\
\text { study } \\
\text { education } \\
\text { alterity } \\
\text { life in common } \\
\text { peace } \\
\text { kindness } \\
\text { interaction }\end{array}$ \\
\hline
\end{tabular}

In order to learn about the different positioning of participants related to social values associated with rural, we have identified the formation of clusters of individuals across the valorative content, as shown in Table 5.
Through the projection of social values associated to rural in the factorial plan (see Table 2), it was possible to verify the contribution of clusters in the development of the representational field 'rural people'. In Factor 1, both community internal values (Factor 1 : Test- $\mathrm{V}=3.9$ ) 
and personal values (Factor 1: Test-V $=6.1$ ) cooperate for the resources assessment, and inter-community values (Factor 1: Test-V $=-4.7$ ) reinforce the assessment of the way of life in the first factor.

The dynamics evidenced by the combined analysis between rural values and the representations of 'rural people' contribute to the significance of rural sociability among the subjects of representation.

\section{Discussion}

This study aimed to investigate the social representations of rural sociability among four generations of a rural community in the state of Espírito Santo based on the theoretical framework of the three-phase model (Berti et al, 2008; Bonomo et al. 2013; Doise et al, 1995). From this research proposal, the task was to describe the semantic field related to the representational object 'rural people,' to know the organizing principles of individual positioning in relation to the shared content, and to analyze the psychological, social, and psychosocial anchoring processes, in order to discuss the functions of the representational field for the rural group in question.

By analyzing the results, we identified that the organizing principles of social representations of 'rural people' (Table 2) are guided by three main thematic universes, as follows: sustainability of the rural context, comparison between the rural and urban environments, and rural sociability; the latter marked by the community context and its value system (Carneiro, 2005; Fialho, 2005; Moreira, 2005). Whereas clusters suggest the formulation of different social representations (Berti et al., 2008), we observed a semantic correspondence between the referred thematic units and the groups of subjects with their social representations about the analyzed object, according to the psychological anchoring process identified: agriculturalists (cluster 1), depreciated (cluster 2) and communal (cluster 3).

The sustainability of the rural context associated to the rural the way of life highlights the resources of the country (Factor 1 'evaluation of resources'), a semantic category designed mainly by the agriculturalists and depreciated groups (cluster 1 and cluster 2 - psychological anchoring). Despite the feeling of depreciation, which reflects the context of poverty in many rural realities in Brazil, participants underline positive aspects of a rural that can generate resources and maintain the survival of their people (Fialho,
2005; Moreira, 1999). In line with this dynamic, we also verified that the children of the community (social anchoring), the participants who represent rural as sustainable (cluster 3), and those that have inter-community values (cluster 2) (psychosocial anchoring) also contribute for the development of this image.

Regarding the comparison countryside-city, there are meanings that reveal the precariousness of the rural areas in relation to the urban context and the consequent feeling of depreciation of people from the rural environment (psychological anchoring: cluster 2 depreciated), given the lack of investment in resources and public policies for the rural area (Bonomo, 2010). This representational field, linked to the negative image of being rural (factor 2) is related to the members of the first and third generations (social anchoring) and to those who represent the rural area as a disadvantaged territory (psychosocial anchoring - cluster 2).

In this dimension, we underline the identity paradox experienced by rural youth which has been configured as a social issue in the context of selective exodus, jeopardizing the maintenance of family agriculture (Moreira, 2005) and the reproduction of the local social fabric in many rural areas of the country (Froehlich et al., 2011). Regarding data from the present study, we emphasize, however, that the negative polarity is not placed on the rural sociability but on the depreciation condition in relation to the urban group, holder of resources and power, which can show an also critical and dialogical positioning in relation to belonging to the rurality-urbanity categories (Deschamps \& Moliner, 2009).

Rural sociability, in turn, includes elements of the shared field to which they refer, mainly to social interaction and to the social values related to the community context (Baltazar, 2004; Bonomo \& Souza, 2010; Moreira, 2005), associating to the description of the rural way of life (factor 1) and the positive image of being rural (factor 2), as well as those who emphasize the agricultural and community dimensions (cluster 1 and cluster 3 - psychological anchoring) of rural life. According to the analysis of the psychosocial anchoring processes, people who present community and personal values (cluster 1 and cluster 3 ) and those who see the rural as a space of sustainability and sociability (cluster 3 and cluster 1) contribute to the development of this image. Responsible for the process of defense and transmission of rural sociability (Deschamps \& Moliner, 2009; Souza, 2004), the second and fourth generations (social anchoring) heavily participate in the 
process of construction of these positive social representations about the way of life in the country.

Considering the empirical framework on which the analysis of this study was based, in line with the theoretical reference input (Doise, 2002; Doise et al., 1995), we found that the members of the rural group use strategies that aim at the preservation of the rural way of life, according to the identity function of social representations (Abric, 2003). The rural area is considered as a context in which the socialization of individuals is geared towards agricultural work and communal relations, and rural sociability is regarded as positive, even in a context of fragility of objective resources (Moreira, 2005).

The investment in a value system that reinforces the personal and group characteristics perceived as positive also acts favorably to the development of a representational field oriented for the defense and protection of rural and community life, as shown in the analysis of the psychosocial anchoring process. In this sense, we verified that social representations are intrinsically linked to the attributes of social groups, guiding processes of social identification and affirmation of differences in relation to oppositional groups in the established social relationship (Abric, 2003; Deschamps \& Moliner, 2009; Doise, 2002; Moscovici, 1978; Souza, 2004). This dynamic helps to maintain the positive image of the group and to strengthen the group's belief system, responsible for the ideological rhetoric of rural identity and its transmission to new generations (Breakwell, 2001; Howarth, 2006; Jodelet, 2001; Tajfel, 1982).

\section{Final Considerations}

The development of this study is centered on the task of investigating the social representations of 'rural people' among residents of a rural community in the state of Espírito Santo. Among the main results, we identified three semantic units guiding the construction of the social object in analysis, namely: (i) comparison between the rural and urban contexts, highlighting the criticism of community members about the lack of public policies aimed at the rural context, a reality that is reflected in the representation of the rural as disadvantaged and in the elaboration of the feeling of depreciation among community members; (ii) sustainability, a theme that evokes the idea of a rural that, despite the lack of investment of external funds, can generate strategies and own resources to ensure the objective and symbolic survival of the group; and (iii) rural sociability, which synthesizes community efforts to maintain and transmit prominent identity elements of the rural community way of life.

Considering the theoretical and methodological planning of this study, as well as its results, among the possible contributions of this work we highlight the possibility of expanding the scientific knowledge produced on the Brazilian rural population in the area of Psychology, especially from a phenomenological perspective focused on identity and representational processes, which have guided social mobility processes, particularly among rural youth. It is also noteworthy the fact that we used the three-phase model methodological approach, still little disseminated among researchers in the country (Almeida, 2009).

Limitations found in the development and analysis of the results obtained in this study reveal new research tasks: expansion of the sample to other community settings; links between the group's history and its value and representational systems; further deepening of the variables gender and generation in the analysis of identity processes linked to the rural context; and study of the relationship between generation, rurality representations, and motivations to stay or emigrate from rural territories of reference.

\section{References}

Abric, J. C. (2003). L'analyse structurale des representations socials. In S. Moscovici, \& F. Buschini (Orgs.), Les méthodes des sciences humaines (pp. 375392). França: Puf Fondamental.

Almeida, A. M. O. (2009). Abordagem societal das representações sociais. Sociedade e Estado, Brasília, 24 (3), 713-737. doi: 10.1590/S0102-69922013000100006.

Andersén, A. (2010). Social Representations and Social Identity in Swedish Folk High Schools: an application of Duveen and Lloyd. Papers on Social Representations, 19 (1), 1-10. Retirado de: http:// psych1.1se.ac.uk/psr/PSR2010/19_10Andersen. pdf

Baltazar, B. (2004). Os encontros e desencontros da militância e da vida cotidiana. Psicologia: Teoria e Pesquisa, 20 (2), 183-190. doi: 10.1590/ S0102-37722004000200011.

Bardin, L. (2002). Análise de conteúdo. Lisboa: Edições 70. 
Bardin, L. (2003). L'analyse de contenu et de la forme des communications. In S. Moscovici, \& F. Buschini (Orgs.), Les méthodes des sciences humaines (pp. 243-270). Paris: Puf Fondamental.

Berti, C., Pivetti, M., \& Melotti, G. (2008). Dal "public understanding of science" allo "scientific understanding of public": rappresentazioni sociali del progetto genoma umano. Psicologia sociale, 2, 283-306.

Bonomo, M. (2010). Identidade social e representações sociais de rural e cidade em um contexto rural comunitário: campo de antinomias. Tese de Doutorado, Centro de Ciências Humanas e Naturais, Universidade Federal do Espírito Santo, Vitória.

Bonomo, M., \& Souza, L. (2010). Do território à cultura comunitária: representações sociais de comunidade. Revista Electrónica de Psicología Política, 23, 1-50.

Bonomo, M., Souza, L., Melotti, G., \& Palmonari, A. (2013). Princípios organizadores das representações de rural e cidade. Sociedade e Estado, 28 (1), 91-118. doi: 10.1590/S0102-69922013000100006.

Breakwell, G. M. (2001). Social Representational Constraints upon Identity Process. In K. Deaux \& G. Philogène. (Eds.), Representations of the Social (pp. 271-284). Oxford: Blackwell.

Carneiro, M. J. (2005). Apresentação. In R. J. Moreira (Org.), Identidades sociais: ruralidades no Brasil contemporâneo (pp. 7-13). Rio de Janeiro: DP\&A.

Clémence, A., Doise, W., \& Lorenzi-Cioldi, F. (1994). Prises de position et príncipes organisateurs de représentations sociales. In C. Guimelli (Org.), Texte de base em sciences sociales. Structures et transformations des représentations sociales (pp. 73 - 84). Paris: Delachaux et Niestlé.

De Rosa, A. S. (2003). Le "réseau d'associations" - une technique pour détecter la structure, les contenus, les indices de polarité, de neutralité et de stéréotypie du champ sémantique liés aux representations socials. In J. C. Abric (Org.), Méthodes d'étude des représentations sociales (pp. 81-117). Ramonville Saint-Agne: érès.

Del Priore, M., \& Venâncio, R. (2006). Uma história da vida rural no Brasil. Rio de Janeiro: Ediouro.

Deschamps, J. C. (2003). Analyse des correspondances et variations des contenus de représentations socials. In J. C. Abric (Org.), Méthodes d'étude des représentations sociales (pp. 179-199). Ramonville Saint-Agne: érès.

Deschamps, J. C., \& Moliner, P. (2009). A identidade em psicologia social - Dos processos identitários às representações sociais. Petrópolis: Editora Vozes.

Doise, W. (1989). Livelli di spiegazione in psicologia sociale. Milano: Giuffrè editore.

Doise, W. (2002). Da psicologia social à psicologia societal. Psicologia: teoria e pesquisa, 18 (1), 27-35.

Doise, W., Clémence, A., \& Lorenzi-Cioldi, F. (1995). Rappresentazioni sociali e analisi dei dati. Bologna: Il Mulino.

Duveen, G. (2001). Representations, Identities, Resistance. In K. Deaux \& G. Philoguène (Eds.), Representations of the Social (pp. 257-270). Oxford: Blackwell.

Duveen, G. \& Lloyd, B. (1990). Introduction. In G. Duveen, \& B. Lloyd. (Eds.), Social Representation and the Development of Knowledge (pp. 1-10). Cambridge: Cambridge University Press.

Fialho, M. A. V. (2005). Agricultura familiar, produção orgânica e "novos rurais": um estudo de caso no sul do Brasil. In R. J. Moreira (Org.), Identidades sociais: ruralidades no Brasil contemporâneo (pp. 109-126). Rio de Janeiro: DP\&A.

Froehlich, J. M., Rauber, C. C., Carpes, R. H., \& Toebe, M. (2011). Exxodo seletivo, masculinização e envelhecimento da população rural na região central do RS. Ciência Rural, 41 (9), 1674-1680.

Howarth, C. (2002). Identity in whose eyes?: The role of representations in identity construction. Journal for the theory of social behavior, 32 (2), 145-162.

Howarth, C. (2006). A social representation is not a quiet thing: Exploring the critical potential of social representations theory. British Journal of Social psychology, 45, 65-85.

Instituto Brasileiro de Geografia e Estatística (2010). Censo 2010. Retirado de: http://www.censo2010. ibge.gov.br/

Jodelet, D. (1998). A alteridade como processo e produto psicossocial. In A. Arruda (Org.), Representando a alteridade (pp. 47- 67). Rio de Janeiro: Vozes.

Jodelet, D. (2001). As representações sociais. Rio de Janeiro: EdUERJ. 
Lebart, L., Morineau, A., Becue, M., \& Haeusler, L. (1994). SPAD-T - Manuel de l'utilisateur. Saint-Mondé, France: Cisia - Centre International de statistique et d'informatique appliquées.

Mainwaring, S. (2004). A igreja católica e a política no Brasil. São Paulo: Brasiliense.

Moreira, R. J. (1999). Agricultura familiar: processos sociais e competitividade. Rio de Janeiro: Mauad.

Moreira, R. J. (2005). Ruralidades e globalizações: ensaiando uma interpretação. In R. J. Moreira (Org.), Identidades sociais: ruralidades no Brasil contemporâneo (pp. 15-40). Rio de Janeiro: DP\&A.

Moscovici, S. (1978). A representação social da psicanálise. Rio de Janeiro: Zahar Editores.

Nosella, P. (2007). Origens da pedagogia da alternância. Brasília: UNEFAB.

Souza, L. (2004). Processos de categorização e identidade: solidariedade, exclusão e violência. In L. Souza,
\& Z. A. Trindade (Orgs.), Violência e exclusão: convivendo com paradoxos (pp. 57-74). São Paulo: Casa do Psicólogo.

Stropasolas, V. L. (2006). O mundo rural no horizonte dos jovens. Florianópolis: Ed. UFSC.

Tajfel, H. (1982). Grupos bumanos e categorias sociais II. Lisboa: Livros Horizonte.

Vala, J., \& Lima, M. (2002). Individualismo meritocrático, diferenciação, cultural e racismo. Análise Social, 37 (162), 181-207.

Villano, P., Bastianoni, P., \& Melotti, G. (2001). Representation of the serial killer on the italian internet. Psychological Reports, 89, 447-451.

Recebido em: 23/06/2015

Reformulado em: 10/03/2016; 16/03/2016

Aceito em: 16/03/2016 
Sobre os autores:

Mariana Bonomo é professora do Departamento de Psicologia Social e do Desenvolvimento e do Programa de PósGraduação em Psicologia da Universidade Federal do Espírito Santo, com doutorado e pós-doutorado em Psicologia pela UFES.

E-mail:marianadalbo@gmail.com

Lídio de Souza (in memoriam) é doutor em Psicologia Social pela Universidade de São Paulo, foi professor do Programa de Pós-Graduação em Psicologia e do Departamento de Psicologia Social e do Desenvolvimento da Universidade Federal do Espírito Santo (1984-2012).

Paola Zanotti Epifanio é graduada e mestre em Psicologia pela Universidade Federal do Espírito Santo. E-mail: zanottiepifanio@gmail.com

Zeidi Araujo Trindade é professora titular da Universidade Federal do Espírito Santo, vinculada ao Departamento de Psicologia Social e do Desenvolvimento e ao Programa de Pós-Graduação em Psicologia, com doutorado e pósdoutorado em Psicologia pela Universidade de São Paulo.

E-mail: zeidi.trindade@gmail.com

Contato com os autores:

Mariana Bonomo

Programa de Pós-Graduação em Psicologia. Centro de Ciências Humanas e Naturais Universidade Federal do Espírito Santo

Av. Fernando Ferrari, 514

Campus Universitário Goiabeiras

Vitória-ES, Brasil

CEP: 29075-910

Telefone: (27) 4009-2501 